\section{TASA-ARVON POLITIIKKAA}

Kirsti Lempiäinen: professori ma., aikuiskasvatuksen sosiologia, Lapin yliopisto

Johanna Kantola \& Paula Koskinen Sandberg \& Hanna Ylöstalo (toim.): Tasa-arvopolitiikan suunnanmuutoksia. Talouskriisistä tasa-arvon kriiseihin. - Gaudeamus, Helsinki. 2020, 328 s.

Tasa-arvopolitiikan suunnanmuutoksia -teoksessa pureudutaan nimenmukaisesti uusiin painotuksiin tasa-arvon ymmärtämisessä ja edistämisessä. Edistys ei suinkaan aina ole yksiviivaisen suoraa, vaan välillä tasa-arvoasiat näyttävät vähemmän merkityksellisenä politiikan käytännöissä. Vaikka suomalaisen hyvinvointivaltion tai hyvinvointiyhteiskunnan rakentamisessa tasa-arvolla ja yhdenvertaisuudella on kiistämättä keskeinen asema, se voidaan tämänkin teoksen perusteella välillä työntää takaalalle ja ikään kuin unohtaa hetkeksi. On hyvä, että tasa-arvotutkimusta tehdään, jotta saamme lukea ja opiskella sitä, mitä tasa-arvoasioissa juuri nyt on meneillään, millaista merkitystä niillä on yhteiskunnassa ja miten tähän päivään on tultu.

Kirjan toimittajat Johanna Kantola, Paula Koskinen Sandberg ja Hanna Ylöstalo korostavat johdannossaan, että teos pohjaa tasa-arvon politiikkaan, toisin sanoen toimittajat laventavat ja syventävät tutkittavaa tematiikkaa. Haluan jo heti alkuun tähdentää, että tämä kirja kuuluu laajasti kriittisen yhteiskuntatutkimuksen oppikirjaksi korkeakouluihin ja että toivon mukaan se on jo päätynyt poliittisten päättäjien ja yhteiskunnallisten toimijoiden luettavaksi.

Kirjan rakenne on selkeä. Toimittajien kirjoittaman analyyttisen johdannon jälkeen teoksen luvut on jaettu kolmeen osaan, joista ensimmäisessä käsitellään tasa-arvopolitiikan pysyvyyttä, jatkuvuutta ja muutosta Euroopan unionin, talouspolitiikan ja oikeudellisen ajattelun näkökulmista. Toinen osa on otsikoitu "Kamppailu tasa-arvosta - ja feminismistä", ja siinä tutkitaan eroja ja eriarvoisuutta, tuodaan uusia käsitteitä suomalaiseen keskusteluun sekä tarkastellaan tasa-arvoa suomalaisessa ulkopolitiikassa kylmän sodan historiasta nykypäivään. Kolmannessa osassa keskitytään työmarkkinoihin ja hoivaan. Tasa-arvon erittelyn kohteina ovat samapalkkaisuus, tasa-arvopuhe eduskunnassa, prekaarius ja ay-toiminta, vanhuus ja vaiva sekä ammatillinen toimijuus erityisessä lean-työnjohto-opissa. Loppuluvussa toimittajat esittävät vielä perustelunsa sille, miksi tarvitaan kriittistä tasa-arvolukutaitoa.

Kiinnostava havainto ja tutkimustulos EU-tasolta on se, että erillisiä ohjelmia tai budjetointeja ei enää aikaisempaan tapaan suunnata tasa-arvon edistämiseen. Samaan aikaan tasa-arvo on käsitteenä lähes hävinnyt rahoitusohjelmista. EU-tason tasa-arvopoliittiset heikentymiset näkyvät myös Suomessa tasa-arvokentän haurastumisena. Anna Elomäen ja Johanna Kantolan mukaan onneksi on olemassa vastakkaisia tendenssejä, kuten uusien vahvojen poliittisten toimijoiden sitoutuminen tasaarvon edistämiseen. 
Talouskriisit 1990- ja 2000-luvuilla ovat vaikuttaneet monin tavoin yhteiskuntaan, niin myös tasa-arvon käytäntöihin ja politiikkoihin, ja voi vain arvailla, miten meneillään oleva koronaviruspandemia kytkeytyy moninaiseen tasa-arvoon. Taloudesta on esitettävä tasa-arvokysymyksï. Elomäki ja Hanna Ylöstalo esittävätkin omassa analyysissaan, että politiikanteko on taloudellistunut, millä on vaikutuksensa tasa-arvotilaan. Taloudellistuminen liittyy hyvinvointivaltion murrokseen, julkishallinnon ja -johtamisen markkinahenkistymiseen sekä uusliberaaliin hallintaan, jossa tasa-arvoa ei nähdä strategisena asiana. Sukupuolten tasaarvoa ehkä arvostetaan, mutta siitä vallitsee strateginen hiljaisuus. Elomäen ja Ylöstalon oma talouspolitiikka on feminististä, ja siinä nostetaan etualalle sukupuolitietoinen budjetointi ja sukupuolivaikutusten erittely. Nämä keinot eivät yksistään riitä, jos ymmärrys taloudesta on sukupuolisokea. Heidän mukaansa esimerkiksi julkiset hoivapalvelut voitaisiin käsittää "sosiaalisen infrastruktuurin investointeina, jotka hyödyttävät taloutta sekä lyhyellä että pitkällä aikavälillä” (s. 65).

Yhdenvertaisuuden käsite on Johanna Niemen mukaan tasa-arvo-oikeudessa vahvistunut eli sukupuolten tasa-arvon rinnalla keskitytään myös esimerkiksi etnisyyteen, vammaisuuteen ja ikään. Niemen päätelmä tangeeraa feministisen tutkimuksen intersektionaalisuuden näkökulman kanssa, jossa korostetaan sukupuolen lisäksi muita yhteiskunnallisia erontekoja, kuten vaikkapa yhteiskuntaluokkaa tai ihonväriä. Veronika Honkasalon ja Titus Hjelmin analyysissa turvapaikkauutisoinnista intersek- tionaalinen lähtökohta on keskeinen. Uutisoinneissa erot näyttävät peittyvän suomalaiset ja muut -asetelmaan tavalla, jossa Suomi ja suomalaiset ovat tasaarvoisia ja muualta tulevilla on stereotyyppisesti omanlaisensa kulttuuri.

Myös sukupuolta voidaan ajatella moninaisena. Nina Järviön analyysi translaista ja transpolitiikasta osoittaa, että meidän tulisi päästä eroon kahtiajaoista ja normatiivisista vastakkainasetteluista, jotta tasa-arvossa voidaan edetä. Pysyvän ja muuttuvan, normaalin ja epänormaalin, selkeän ja epäselvän rajoista on syytä käydä jatkuvaa keskustelua, sillä kahtiajakoja ja vastakkainasetteluja on vaikea hallita. Oikeudenmukaista olisikin, että sukupuolen moninaisuutta pyrittäisiin tasa-arvopolitiikassa painottamaan, jolloin myös transpolitiikalle olisi nykyistä enemmän tilaa.

Järviön teksti nivoutuu mainiosti myös muuttuvan feministisen toimijuuden pohdintaan (Elomäki, Kantola, Anu Koivunen ja Ylöstalo). On kiinnostavaa pohtia sitä, miten syvälle hallinnon ja hallinnan rakenteisiin ja poliittisiin strategioihin feministit ovat valmiita menemään. Kun tasa-arvon periaatteista ollaan valmiita käymään kauppaa, saattaa hallinta alkaa määrittää omaa toimintaa. Feministitoimija voi toki lamaantuakin tasa-arvovastaisessa yhteiskunnallisessa ilmapiirissä. Tasa-arvo- ja feministitutkijat ovat puolestaan pyrkineet luomaan uusia kumppanuuksia ja vaikuttamisen tapoja. Uudessa feministisessä toiminnassa feminismi nostetaan naissukupuolta tärkeämmäksi. Uudet feministitoimijat vastustavat rasismia, puolustavat sukupuolen moninaisuutta, toimivat myös henkilöbrändeillä ja 
kaupallisilla tavoilla. Elomäki, Kantola, Koivunen ja Ylöstalo esittävät, että yksilöllisen ja yhteisöllisen feminismin muotoja on monia, eikä yhtä feministisen vaikuttamisen tarinaa Suomessa kannata tavoitella.

Toisen osan päättää Suomen ulkosuhteita käsittelevä luku, jossa tasaarvopolitiikkaa kehystetään "kylmän sodan YK-feminismistä 2010-luvun tolkkutasa-arvoon" (Marjaana Jauhola ja Minna Lyytikäinen). Tutkijat tarkastelevat feministisen ulkopolitiikan mahdollisuutta, Helvi Sipilän ja YKpolitiikan painotuksia, 2000-luvun naisten oikeuksia ja tasa-arvokysymystä. "Pohjoismaisella ulkopolitiikan tolkkutasa-arvolla" he tarkoittavat linjaa, jossa naiserityinen rauhanvälitys annostellaan turvallisuuspolitiikkaan sopivaksi ("lisää naiset ja sekoita -politiikka"). Tulevaisuudessa olisi Jauholan ja Lyytikäisen mukaan oltava enemmän tilaa valtioiden rajat ylittävälle feministiselle politiikalle.

Kolmas osa alkaa korporatistisen järjestelmän ja samapalkkaisuuden tarkastelulla (Paula Koskinen Sandberg). Koskinen Sandberg esittää, että korporatismista johtuen tasa-arvopolitiikka on Suomessa ollut vaatimatonta vaikuttavuudeltaan. Työmarkkinajärjestöjen palkoista sopiminen ja neuvottelut kulkevat omaa rataansa ja tasa-arvon edistäminen laissa omaansa. Miikaeli Kylä-Laaso analysoi sivuutettua sukupuolta eduskunnan tasa-arvopuheessa. Kilpailukykysopimus ja pakkolait ovat kyseenalaista lähihistoriaamme, jota Kylä-Laaso tutkii osana korporatistista valtakamppailua, jossa kilpailun ja tasaarvon käsitteet lyövät toisiaan korville.
On kiinnostavaa nähdä, millä ehdoilla korona-Suomea elvytetään ja miten elvytyksessä käy tasa-arvon edistämiselle.

Haurastuva palvelutyö ja muutoksen tarpeet ammattiyhdistystoiminnassa ovat seuraavan luvun pääteemat. Ville Kainulainen tarkastelee luottamusmiesten roolia työpaikoilla, heidän toimijuuttaan "kaksoisagentteina" sekä työpaikan että liiton toimijoina. Paikallisen sopimisen lisääntyminen aiheuttaa ay-toiminnalle haasteita samaten kuin vaikkapa kielen vuoksi erilaisissa asemissa olevien työntekijöiden etujen puolustaminen. Kainulainen näkee tulevaisuudessa aktiivisemman ja osallistavamman ay-toiminnan saavan jalansijaa suomalaisessa palvelutyössä. Haurastuvasta palvelutyöstä siirrytään hoivan, vanhuuden ja tasa-arvon kysymyksiin. Vaiva-kollektiivi (Olli Karsio, Lena Näre, Antero Olakivi, Liina Sointu ja Minna Zechner) käyttää sanaa vaiva hoivan tilalla nostaakseen esiin hoivan eriarvoistumisen erityisesti vanhoilla ihmisillä. Omaisten vastuu hoivan järjestämisessä ja antamisessa on kasvanut, ja hoivavastuu jää usein naisten kontolle. Tutkijoiden mukaan "vaivaisuuden" tulisi näkyä hoivapolitiikassa ja eriarvoisiin mahdollisuuksiin saada hoivapalveluja tulisi puuttua.

Toimijuuden näkökulma jatkuu niin sanotun hyvinvointityön lean-ajattelun analyysissa. Yksinkertaisesti muotoillen lean-mallissa pyritään työ tekemään mahdollisimman, jopa pedanttisen tehokkaasti. Työ vakioidaan, työntekijät innostetaan, visuaalisuuden merkitystä suoritteissa korostetaan ja tunteet valjastetaan mukaan. Sukupuoli, ammattiasemien hierarkiat ja muut erot jäte- 
tään syrjään. Helena Hirvonen, Laura Mankki, Iiris Lehto ja Eeva Jokinen esittävät, että tunteilla johtamisessa työntekijät ovat haavoittuvimmillaan. Niin ikään toimijoiden asiantuntijuus hämärtyy, kun organisaation kulttuuriin sitoudutaan olemalla "enemmän kuin sankareita". Tasa-arvopolitiikan kannalta standardeihin ja mitattavuuteen perustuva lean-ajattelu on hankala, sillä siinä ei ole keinoja käsitellä erilaisuutta ja eriarvoisuutta. Hirvonen, Mankki, Lehto ja Jokinen kysyvät viitaten Vaiva-kollektiivin analysiin, miten käy esimerkiksi yksin asuville vanhuksille, jotka tarvitsevat palveluja, jotka eivät ole standardin mukaisia. Kysymys on tärkeä.

Teoksen luettuani jäin miettimään sitä, että korkeakouluissa ei laajalti opeteta kriittistä tasa-arvolukutaitoa. Teos osoittaa kohtia, joihin yhteiskuntatutkimuksessa ja tasa-arvopolitiikan käytännöissä tulee kiinnittää huomiota, joita pitää tutkia lisää ja joista opetuksessa voidaan keskustella. Tästä on hyvä jatkaa.

\section{OPINIONSBILDNING OCH FUNKTIONSNEDSATTAS RÄT- TIGHETER}

Mikael Nygård: professor i socialpolitik, Åbo Akademi

Jörgen Lundälv: Pennskaften inifrån. Ideologiska krafter om modern funktionshinderspolitik i Finland och Sverige. Premiss förlag, Stockholm. 2019, $472 \mathrm{~s}$.

Vilken betydelse har litterär verksamhet och debatt i socialpolitiken, och hur kan litterära gräsrotskrafter medverka till ett mer socialt rättvist samhälle? Dessa är några av de frågor som behandlas i Jörgen Lundälvs nya bok Pennskaften inifrån om ideologiska krafter och modern funktionshinderpolitik i Finland och Sverige (2019). Närmare bestämt avser boken att belysa hur funktionsnedsattas rättigheter förs fram och debatteras i Finland och Sverige i dag, men kopplar även samman denna debatt med litterära förgrundsgestalter i historien. Syftet med boken är att "berätta om den kunskap och erfarenhet som finns i de två nordiska länderna om olika debattlinjer och debattvågor inom funktionshinderområdet och mänskliga rättigheter" (s. 40). Detta görs genom att återge svaren från ett tjugotal intervjuer med personer i Finland och Sverige - personer som på olika sätt agerat för att lyfta upp funktionsnedsattas rättigheter på dagordningen, men som också försöker påverka de rådande attityderna och samhällsstrukturerna. Boken kan därmed ses som ett bidrag till en större diskussion om vad som har hänt med samhällskritiken 
inom socialpolitiken och det sociala arbetet i Sverige, men även i andra nordiska länder såsom Finland.

Vad är då ett "pennskaft", och vad står egentligen metaforen "pennskaften inifrån" för? Denna tankefigur används för att visa hur enskilda människor, allt från författare till olika eldsjälar inom funktionshinderpolitiken, via sina pennor kan forma och bidrag till (de)konstruktionen av begrepp såsom funktionsnedsättning eller sociala/ mänskliga rättigheter, samt de tankeramar och hinder som står i vägen för ett $i$ detta avseende jämlikt samhälle. Vi talar här dock inte om vilka aktörer som helst, utan de som agerar "inifrån", det vill säga de som på olika vis skriver utgående från egna erfarenheter av funktionsnedsättning, utan att för den skull själv behöva tillhöra denna kategori. De bidrar på så sätt till att berätta de funktionshindrades historia och föra fram deras talan "inifrån". Det är med andra ord en slags "frigörandets praktik" vi har att göra med, en praktik som handlar om att ifrågasätta dominanta diskurser och kategoriseringar som vidmakthåller ableism, diskriminering och ojämlikhet.

Att läsa "Pennskaften inifrån" ger inte enbart en ökad förståelse av hur synen på funktionshinder utvecklats genom tiderna utan också vilken roll litterär verksamhet och opinionsbildning bland journalister, aktivister samt oli$\mathrm{ka}$ företrädare för organisationer och föreningar inom området spelar för att bejaka funktionsnedsattas rättigheter. Bokens budskap är att "pennskaftlig verksamhet" har en betydelse för att de utsattas röst, i detta fall människor med någon form av funktionsnedsättning, ska höras i samhällsdebatten och även spela roll i det politiska beslutsfattandet och det sociala arbetet. Metaforen "pennskaft" är såtillvida välvald, eftersom det syvende och sist handlar om den inneboende kraft som pennan har. Pennan kan ju som bekant många gånger vara mäktigare än svärdet.

Boken tar sitt historiska avstamp i fem kvinnliga samhällskritiker från slutet av 1800-talet och första delen av 1900-talet: Minna Canth, Elin Wägner, Maria Sandel, Hella Wuolijoki och Hilja Pärssinen. Dessa kvinnor lyfte via sin litterära och politiska verksamhet på olika sätt lyfte fram orättvisorna och klasskillnaderna $i$ det förindustriella samhället, och speciellt då kvinnans underordning. Dessa författare ägnade, $i$ likhet med andra samtida författare, visserligen frågor om funktionsnedsattas rättigheter ringa uppmärksamhet, men kan ändå sägas ha bidragit till en emanciperande och medvetandegörande diskurs som under 1900-talets senare hälft successivt även började gälla funktionsnedsatta. Det ska dock påpekas att dessa författare inte var de enda som kan anses ha haft betydelse för synliggörandet av de funktionshindrades ställning och rättigheter. Till exempel spelade de finska "katedersocialisterna" företrädda av bland annat Yrjö Sakari Yrjö-Koskinen en snarlik roll i Finland vid förra sekelskiftet, medan Myrdalarna kan anses ha haft en motsvarande roll i Sverige på 1900-talet. Det framgår inte heller av boken hur framväxten av välfärdstjänster och ökade rättigheter för funktionsnedsatta var kopplade till dessa tidiga "pennskaft". Inte desto mindre finns det en koppling som går via synliggö- 
randet av ojämlikhets- och klassfrågor till folkhemmet och den moderna välfärdsstaten.

Det som kanske ändå kan ses som bokens viktigaste bidrag är dess berättelse om hur "pennskaften" opererar inifrån i dagens Finland och Sverige. Författaren har härvidlag intervjuat ett antal aktörer och opinionsbildare i bägge länder och därtill analyserat en rad texter av författare för att visa hur dessa bidragit till att synliggöra och förfäkta de funktionshindrades rättigheter $\mathrm{i}$ dagens samhälle. Denna genomgång visar med tydlighet den kraft som "pennskaften" har, och den viktiga roll som dessa aktörer spelar vid sidan av offentliga myndigheter och olika medborgarorganisationer. Samtidigt tyder genomgången på att ableismen, dvs. normaliseringen av den friska kroppen och funktionsförmågan, fortfarande verkar ha en dominant ställning i samhället, och även inom delar av det sociala arbetets och socialservicens praktiker. Även om mycket har gjorts för att hävda och öka funktionsnedsattas rättigheter i Finland och Sverige, finns det fortfarande hierarkier samt kategoriserande och även diskriminerande praktiker som vidmakthåller ojämlikhet och utanförskap, till exempel i fråga om funktionsnedsattas deltagande på arbetsmarknaden. Och det blir inte heller bättre av att de funktionshindrades röst inte alltid tillåts höras i de massmediala kanalerna eller inom politiken. Allt detta innebär att det ännu finns en del att göra för att de historiska "pennskaftens" ambition om ett socialt rättvist samhälle ska kunna infrias. Samtidigt visar boken på den outsinliga vilja och den kraft som pennan har i händerna på opinionsskapande och politiserande krafter, och det- ta känns i sin tur inspirerande och uppmuntrande i kampen för ett mer jämlikt och socialt rättvist samhälle.

\section{KESKIPISTEESSÄ PÄIHDEON- GELMAISTEN ASIAKKAIDEN OIKEUDET}

Teija Karttunen: YTT, sosiaalityön esimies, Psykososiaaliset palvelut, Vantaan kaupunki

Aini Pehkonen \& Taru Kekoni \& Katja Kuusisto (toim.): Oikeus päihdehuoltoon.Vastapaino, Tampere. 2019, 355 s.

Vastapaino julkaisi syksyllä 2019 Aini Pehkosen, Taru Kekonin ja Katja Kuusiston toimittaman kokoomateoksen "Oikeus päihdehuoltoon". Teoksen tavoitteena on kuvata päihdehuollon nykytilaa, asiakkaiden mahdollisuuksia saada tarkoituksenmukaista, oikea-aikaista sekä yksilöllisiin tarpeisiin vastaavia päihdehoidon palveluja. Johdantoluvun otsikointi "On aika puhua päihdeongelmaisten asiakkaiden oikeudesta päihdehuoltoon" viittaa selkeästi läpi kirjan kulkevaan viestiin sosiaali- ja terveydenhuollon ammattilaisille ja poliittisen päätöksenteon toimijoille: on aika nostaa esille tämän usein yhteiskunnan marginaaliin ja haavoittuvaan asemaan sijoittuvan asiakasryhmän asia ja oikeudet. Ei ole itsestään selvää, että päihdeongelmaiset asiakkaat nähdään subjekteina, oman tilanteensa asiantuntijoina ja muiden kanssa yhtäläiset oikeudet omaavina yhteiskunnan jäseninä. Suomalaisen päihdehuollon, päihdepolitiikan sekä näihin kutoutuvan päihteidenkäyttökulttuurin keskinäiset suhteet ja dynamiikka osana 
yhteiskunnan, sen hyvinvointivaltion ja oikeusjärjestelmän kehityshistoriaa tuottavat tähän oikeusnäkökulmaan nykyhetkessä oman sävynsä.

Kirjan tulokulma on päihdeongelmaisten asiakkaiden ja heidän läheistensä oikeuksia, niiden toteutumista, palveluihin pääsyä, mahdollisuuksia, kynnyksiä ja haasteita pohtiva ja erittelevä. Päihdeongelmaisten asiakkaiden oikeuksien toteutumismahdollisuuksia erilaisin aineistoin ja painotuksin tarkastelee 18 päihdeongelmien kenttää ja substanssia tuntevaa kirjoittajaa. $\mathrm{Mu}-$ kana on tutkijoita, yliopistojen ja ammattikorkeakoulujen opettajia, järjestöjen edustajia ja kentän toimijoita. Teos on suunnattu tutkijoille, opiskelijoille, käytännön sosiaali- ja terveydenhuollon sekä opetus- ja kasvatusalan ammattilaisille.Tämä huomioiden teoksen rakenne ja sisältö on koottu selkeäksi kokonaisuudeksi. Kentän toimijoiden näkökulmasta teos ei myöskään ole liian raskas ja onnistunut teemajaottelu mahdollistaa kohdennetusti itseä kiinnostaviin kysymyksiin paneutumisen.

Kokoomateoksen 12 artikkelia on jaettu kolmeen temaattiseen kokonaisuuteen, jotka liikkuvat lainsäädännön, palvelujärjestelmän, asiakkaiden elämäntilanteiden ja kokemusten, työntekijöiden työn ja ammattikäytäntöjen tasoilla. Ajallisesti artikkeleissa liikutaan kehittyvän hyvinvointivaltion ja sen palveluiden historian sekä nykytilanteen välillä, kieltolaista ja sen kumoamisesta korvaushoidon aikaan, puntaroidaan hallitusohjelmia ja suunnataan tulevaan. Ei ole helppo tehtävä esittää jäsentynyttä kokonaiskuvaa päihdehuollon kentästä ja sen ammattilaisten toiminnasta ja siitä, miten asiakkaat osallistuvat ja kokevat, miten oikeuksia toteutetaan ja miten tähän kaikkeen kutoutuvat päihde- ja sosiaalipolitiikka, juridinen säätely ja oikeudellinen eetos sekä yhteiskunnallisten olosuhteiden muutokset. Päädyn kuitenkin itse siihen, että kokonaisuus on onnistunut, ehyt ja varsin kattava.

Kokoomateoksen ensimmäinen temaattinen kokonaisuus, (I) asiakkaan asema päihdehuollossa, lähestyy päihdeongelmaisten asiakkaiden asemaa ja oikeuksia erityisesti oikeusnormien, hyvinvointivaltion ja päihdepoliittisten linjausten kehityksen ja nykytilan näkökulmasta. Kokonaisuuden aloittaa kattava esitys päihdehuollon ja sosiaalisten oikeuksien kehityksestä, jonka myötä Suomeen saatiin laaja päihdehuollon erityispalvelujärjestelmä (Kaukonen).Teksti osoittaa, miten merkittävä asema sosiaalisten ongelmien käsitteellistämistavoilla, sosiaalisten oikeuksien edistämisellä, niihin liittyvällä keskustelulla ja erityislainsäädäntöä koskevilla tulkinnoilla on sille, miten ja millaisista ideologisista lähtökohdista käsin kansalaisten tuen ja palvelujen tarpeisiin vastataan. Tämän temaattisen kokonaisuuden kaksi muuta artikkelia syväluotaavat päihdehuoltoa koskevaan oikeudelliseen sääntelyyn, oikeusnormeihin ja niiden taustalla olevaan oikeudelliseen ajatteluun sosiaalityön ja palvelujärjestelmän käytäntöihin peilaten. Kohdennetusti artikkeleissa tarkastellaan ensinnäkin päihdeongelmaisen asiakkaan oikeuksia ja niihin vaikuttavia tekijöitä jäsentämällä kahta toisiinsa nivoutuvaa kokonaisuutta: yksilön oikeutta saada päihdepalveluja ja tarveperustaisuutta päätöksenteon perusteena 
sekä kysymystä palveluiden saatavuudesta (Poikonen \& Kekoni). Toiseksi analysoidaan uuden sosiaalihuoltolain tarjoamia välineitä sosiaalityön käytännöllisinä mahdollisuuksina toteuttaa heikommassa ja haavoittuvassa asemassa olevien asiakkaiden oikeuksia päihdehuollon kontekstissa (Kuusisto \& Kalliomaa-Puha). Kumpikin artikkeli avaa sitä, mikä merkitys työntekijöiden juridiikkaan liittyvällä tiedolla, sen sisäistämisellä ja sovellustaidoilla on tässä. Käytännön työn näkökulmasta huolestuttavana voidaan pitää Kuusiston ja Kalliomaa-Puhan tutkimuksen havaintoa siitä, että uusi sosiaalihuoltolaki ei näytä edistäneen päihdeongelmaisten asiakkaiden asemaa ja toisaalta sosiaalityössä itse lain tuntemus ja soveltaminen näyttää jääneen puutteelliseksi.

Hyvinvointivaltion, päihdepolitiikan ja päihdehuollon kehityskulun kuvaaminen sekä juridisen viitekehyksen esille nostaminen, oikeusnormien selittäminen ja avaaminen ovat koko teoksen ehdottomia vahvuuksia. Ne kannattelevat ja rakenteistavat myös muiden temaattisten kokonaisuuksien jäsentymistä ja ymmärtämistä. Käytännön sosiaali- ja terveydenhuollon toimijoiden näkökulmasta näihin artikkeleihin koottua tietoa on osattu tiivistää laajemmasta tietoaineistosta. Tekstit liittävät palveluiden arkisen toiminnan, tapahtumat ja organisaatiokulttuurin osaksi laajempia yhteiskunnan rakenteita ja (sosiaali) poliittisia linjauksia. Erittäin tärkeänä pidän päihdehuoltoon liittyvän juridisen näkökulman esille ottamista. Toisaalta juridisten normien soveltaminen asiakaslähtöisesti edellyttää aina myös päihdeongelmien substanssiin liittyvää asiantuntemusta; näiden kahden alueen riittävä opetus tulisikin turvata sosiaali- ja terveydenhuollon tehtäviin valmistavissa koulutuksissa yliopistoissa ja ammattikorkeakouluissa.

Kirjan toinen temaattinen kokonaisuus, (II) päihdeongelma elämänkulussa, kiinnittyy ihmisten yksityisen elämänpiirin, perheen, vanhemmuuden ja sukupuolen ympärille. Artikkelit on sidottu hyvin lähelle ihmisten mikromaailman kokemuksia. Artikkeleissa painottuvat naisten tilanteet odotus- ja vauvaaikana (Andersson), äitiysidentiteetin näkökulma (Virokannas) ja ikääntyvien naisten häpeäkokemukset (Heino ym.) päihdeongelman yhteydessä. Häpeä, leimautuminen ja epäonnistuminen osana päihdeongelmaisten naisten kokemuksia kertovat laajemmasta yhteiskunnallisesta asennoitumisesta, kulttuurisista ja sosiaalisista normeista. Lapsuuden muistoissa ja elämänkulkua sävyttävissä kokemuksissa liikutaan Henna Pirskasen artikkelissa, jossa kertojina ovat alkoholiongelmaisten isien aikuiset pojat. Yksilötason kokemuksia ja tilanteita analysoivat tekstit tuovat eri näkökulmista esille sen, miten yhteiskunnalliset odotukset ja ideaalit välittyvät ihmisten mikromaailman kokemuksiin myös avun saamisen haasteista ja päihdeongelmasta kuntoutumisen mahdollisuuksista.

Kolmannessa osiossa, (III) päihdehoito ja sen vaikuttavuus, tarkastellaan palvelujen toimivuutta, asiakkaiden asemaa ja heille asettautuvia mahdollisuuksia palvelujen erilaisissa konteksteissa. Toimintaympäristöinä ovat asumispalvelut (Günther \& Ranta), matalan kynnyksen avohuumehoito (Ranta) sekä laitoskuntoutus (Ekqvist \& Kuusisto). 
Teksteissä tulevat näkyviin ne erilaiset ristiriidat ja jännitteet, joiden suhteen sekä asiakkaat että työntekijät pyrkivät luovimaan ja toimimaan. Hyvinkin yksityiskohtaisilla tilannekuvauksilla ja aineistonäytteillä havainnollistetaan hienosävyisen ja tunnustelevan vuorovaikutuksellisen kohtaamisen merkitystä institutionaalisissa rakenteissa. Läpi linjan kulkee pyrkimys tuoda esille asiakkaiden näkemystä, ongelmien monitahoisuutta ja työntekijöiden asettautumista myös ei-tietävään positioon ja etsimään yhteistyössä asiakkaan kanssa toimivia ratkaisuja. Järjestelmä ei aina taivu tai jousta, asiakkaiden elämä ei aina asettaudu organisaatiokaavioihin ja asiakaskriteereihin eivätkä siirtymät palveluista toiseen ole yksiselitteisiä prosesseja.Väistämättä tulee mieleen se kriittinen kysymys, onko palvelujärjestelmä asiakasta varten vai sittenkin asiakas järjestelmää varten. Läpi artikkelien välittyy viesti siitä, että on edelleen tarvetta ja perusteltua järjestää riittävän pitkäkestoista ja intensiivistä hoitoa sekä erimuotoista sosiaalista ja vertaisten tarjoamaa tukea ammatillisen osaamisen rinnalla. Hoito myös vaikuttaa myönteisesti hyvinvointiin, mitä voidaan pitää yhtenä vaikuttavuuden osoittimena (Ekqvist \& Kuusisto). Kokoomateoksen viimeinen tutkimusartikkeli (Partanen \& Kuussaari) palauttaa näkökulman jälleen rakenteiden ja poliittisten tapahtumien tasolle ja sitoo tarkastelun kirjan ensimmäiseen osioon; päihdehuollon kehitys ja painopisteiden muovautuminen (tulevaisuudessakin) ovat sidoksissa laajempiin yhteiskunnallisiin muutoksiin, päihdepoliittisiin sekä sosiaali- ja terveyspoliittisiin linjavetoihin ja ratkaisuihin.
Aivan kokoomateoksen lopussa, viimeisillä sivuilla äänen saa kokemusasiantuntija Elina Tikka. Toimittajilta tämän kokemuspuheenvuoron mukaan ottaminen on ollut onnistunut valinta. Tikan kokemukset konkretisoivat ja henkilökohtaistavat sen, mikä asiakaslähtöisessä päihdekuntoutuksessa toimii ja missä piilevät sen onnistumisen mahdollisuudet: asiakkaaseen ja muutokseen uskomisessa, toivon luomisessa, kunnioituksessa ja kannattelussa - siis sosiaalityön keskeisissä periaatteissa.

\section{ONNISTUNUT VANHUUS ON AKTIIVINEN JA ITSENÄINEN - SAIRAUS JA HAURAUS EIVÄT MAHDU KUVAAN}

Lina Van Aerschot: YTT, tutkijatohtori, Ikääntymisen ja hoivan tutkimuksen huippuyksikkö, Jyväskylän yliopisto

Virpi Timonen: Beyond Successful and Active Ageing. A Theory of Model Ageing. The Policy Press, Bristol. 2016, $119 \mathrm{~s}$.

Niin tutkimuksessa, politiikassa, mediassa kuin bisneksessä keskitytään Virpi Timosen mukaan useimmiten tyylikkäästi harmaantuviin, aktiivisiin ikäihmisiin. Onnistuneesti ikääntyneet ihmiset pitävät huolta itsestään, osallistuvat yhteiskuntaan, pysyvät terveinä ja hoitavat lapsenlapsiaan tai auttavat läheisiään. Heillä on varaa kuluttaa ja nauttia elämästä, kun viimeinkin eläkkeellä on aikaa. Timonen kysyy kirjassaan, mihin ihmeeseen on unohtunut niiden ikääntyneiden joukko, jotka eivät ole hyväkuntoisia, hyvin toimeentulevia, sosiaalisesti aktiivisia ja fyysises- 
ti tarmokkaita. Hän omistaa teoksensa niille, jotka eivät kykene vanhenemaan erityisen onnistuneesti ja aktiivisesti.

Kirjan tavoitteeksi Timonen määrittelee uuden, mallikelpoisen vanhuuden diskursseja tulkitsevan teorian luomisen. Uuden teorian avulla voidaan ymmärtää miten ja millaista onnistuneen vanhuuden mallia yhteiskunnassamme tuotetaan. Tarkastelemalla aktiivisen ja menestyksekkään ikääntymisen ideaaleja voidaan myös analysoida, mikä jätetään huomiotta. Timonen kirjoittaa, että hänen teoriaansa voidaan hyödyntää, kun halutaan tutkia ja ymmärtää niitä ihmisiä, jotka eivät sukupuolensa, sosiaalisen tai etnisen taustansa tai muun yhteiskunnallisen asemansa vuoksi mahdu vallitsevaan onnistuneen ikääntymisen malliin. Kun tiedetään mitä pidetään onnistumisena, voidaan myös määritellä mitä on epäonnistuminen.

Epistemologisen lähtökohtansa Virpi Timonen paikantaa kriittiseen realismiin ja ymmärrykseen sosiaalisesta todellisuudesta näkymättömiin jäävien rakenteiden ja suhteiden määrittämänä. Vaikka ihmiset luovat todellisuutta omien tulkintojensa ja määrittelyjensä kautta eli tuottavat sosiaalisia konstruktioita, kyse ei ole vain abstrakteista tai merkityksettömistä rakennelmista. Sosiaalinen todellisuus on myös oikeasti olemassa.

Timonen etenee kirjassaan kronologisesti paikantaen ensin onnistuneen ja sitten aktiivisen vanhuuden diskurssien kehittymistä. Onnistunutta vanhuutta (successful ageing) on luonnosteltu gerontologisessa tutkimuksessa jo 60-luvulla. Aluksi kyse oli siitä, että negatiivisten heikkenemisen ja luopumisen kuvastojen rinnalle haluttiin tuoda myös positiivinen näkökulma vanhenemiseen. Tutkimuksella osoitettiin, että vanhenemisen ei tarvitse tarkoittaa toimintakyvyn menettämistä ja riippuvuutta muista ihmisistä. Onnistunut vanheneminen koostuu eri hyvinvoinnin osatekijöistä, kuten fyysisestä ja sosiaalisesta aktiivisuudesta, terveistä elintavoista ja tasapainoisesta sekä onnellisuutta edistävästä elämänhallinnasta. Myöhemmin 80-luvulla tutkimuksessa alettiin korostaa, että ihmiset voivat itse määritellä ja valita miten vanhenevat. Timosen mukaan ajatus onnistuneesta ikääntymisestä perustuu oletukselle, että kaikki ihmiset voivat kontrolloida elämäänsä, tehdä valintoja, onnistua ja olla aktiivisia.

Timonen esittää, että onnistuneen vanhenemisen teoriat ovat muuntuneet politiikan käytössä aktiivisen vanhenemisen ihanteeksi, jota tarjotaan vastaukseksi väestön ikääntymisen aiheuttamiin yhteiskunnallisiin ja taloudellisiin kysymyksiin. Ei tarvitse huolestua huoltosuhteen heikkenemisestä tai hoivapalvelujen tarpeen kasvusta, kun puhutaan vain siitä, että ikäihmiset pitävät huolta itsestään, ovat aktiivisia, osallistuvat ja kuluttavat.

Euroopan Unionin julkaisuissa 2000-luvulla on korostettu erityisesti työurien pidentämistä sekä ikäihmisten aktiivista yhteiskuntaan osallistumista vapaaehtoistyön kautta. Lisäksi EU:n julkaisuissa hyvään ja arvokkaaseen vanhuuteen kuuluu itsenäinen asuminen, itsestä huolehtiminen ja kaikenlainen osallistuminen niin pitkään kuin 
mahdollista. Sairaus, vammaisuus, hauraus ja tarvitsevuus jäävät käsittelemättä.

Timosen mukaan on ilmeistä, että kun huomio kiinnitetään voimakkaasti ihmisten omaan vastuuseen ja aktiivisuuteen, sivuun jätetään väestön vanhenemisen mukanaan tuoma hoivan ja avun tarpeiden kasvu, sairauksien aiheuttamat kulut sekä terveys- ja hoivapalvelujen kysynnän lisääntyminen. Vanhojen ihmisten tueksi tarjotaan sosiaalista integraatiota, aktiivista koulutus- ja työvoimapolitiikkaa, ikäystävällistä ympäristöä ja teknologisia apuvälineitä, ei kattavampia hoivapalveluja, tukea ja apua.

Timosen mukaan menestyksekkään ja aktiivisen vanhenemisen diskurssien avulla luodaan malli, jolla väistämättä on myös vastakohta, sillä kaikilta hyvinvointi ja aktiivisuus eivät onnistu. Yhteiskuntatieteellisessä tutkimuksessa pitäisi Timosen mielestä tarkastella miten ja miksi jotkut ihmiset "onnistuvat" vanhenemaan ideaalisen mallin mukaisesti ja toiset eivät.

Osalla ihmisistä olosuhteet ovat epäedulliset, eivätkä he pysty tavoittamaan onnistuneen ja aktiivisen vanhenemisen ihanteita miltään osin. Tutkimuksissa pitäisi tuoda myös näiden ihmisten vanhuuden kokemuksia esiin. Esimerkkinä Timonen käyttää Romaneja Euroopassa ja alkuperäiskansojen jäseniä Australiassa. Kun on koko elämänsä elänyt yhteiskunnan marginaalissa, kokenut syrjintää, jäänyt paitsi koulutuksesta, elänyt köyhyydessä ja saanut vain minimimäärän terveyspalveluja, jos sitäkään, vaikea tilanne tuskin muuttuu vanhuudessa. Timonen korostaa, että aktiivisen ja menestyksekkään ikääntymisen malli on omiaan syventämään jo valmiiksi syrjäytettyjen yhteiskunnan jäsenten tai ryhmien marginalisaatiota.

Aktiivinen vanhuus perustuu resursseille, kuten hyvä terveys ja terveyspalvelujen saatavuus, raha, sosiaaliset suhteet ja sosiaalisen integraation kokemus, psyykkinen hyvinvointi ja ongelmista tai huolista vapaa elämäntilanne. Timonen nostaa esiin psykologisia resursseja, joilla on yhteyttä hyvinvointiin ja elämänhallintaan ja myös hyvään vanhuuteen. Toimintakyvyn tai mahdollisen aktiivisuuden vaaliminen vanhuudessa edellyttää, että ihminen näkee itsensä positiivisesti ja arvostavasti, kokee voivansa hallita elämäänsä sekä kykenee mukautumaan muuttuviin olosuhteisiin. Myös koherenssin tunteella on merkitystä. Sillä tarkoitetaan kokemusta, että elämään ja olosuhteisiin voi vaikuttaa, että ne ovat hallittavissa ja ohjattavissa.

Virpi Timosen kirjan tuloksena esitetään mallikelpoisen vanhuuden teoria (model ageing theory), jossa vedetään yhteen onnistuneen vanhuuden kymmenen oletusta.Vanhuuden mallissa on kyse poliittisista ja taloudellisista intresseistä, yksilöiden oman vastuun ja elämänvalintojen korostamisesta. Nämä ovat mahdollisia ja usein jopa itsestään selviä hyväosaisille ihmisille, mutta vaikeasti saavutettavia tai mahdottomia huono-osaisille.

Beyond Successful and Active Ageing on tervetullut puheenvuoro ikääntymisen, vanhuuden ja hoivan tutkimukseen. Aktiivisuuden oletusten, yksilönvastuun kasvamisen ja menestymisen 
ihanteiden tarkastelua ovat tehneet muutkin tutkijat, mutta Timonen käy kirjassaan seikkaperäisesti läpi, mistä onnistuneen vanhuuden ja aktiivisuuden ihanteet ovat ilmestyneet tutkimukseen, politiikkaan ja julkiseen keskusteluun, mistä ne koostuvat ja millaisia seurauksia niillä on. Kyseessä ei ole mitään uutta, kirjoittaa Timonen, menestyksekäs vanheneminen muodostuu hyvän kehästä, kuten muukin menestys elämässä.

Timonen huomauttaa, että meillä on kovin vähän tutkimusta siitä, miten voidaan auttaa niitä ihmisiä, joiden vanhuusikä on kaukana menestyksen ja aktiivisuuden malleista. Hänen mukaansa emme tiedä oikeastaan mitään siitä, miten väestötasolla voidaan vaikuttaa ja isossa mittakaavassa kääntää "epäonnistunut" vanhuus onnistuneeksi. Timonen ehdottaa, että hyvään vanhuuteen panostetaan parhaiten tukemalla hyvää elämänkulkua. Onnistunut ja aktiivinen vanhuus alkaa rakentua jo lapsuudessa. Siksi hyvän vanhuuden tarkasteluun tarvitaan elämänkulun tarkastelua ja hyvään vanhuuteen satsaaminen täytyy aloittaa tukemalla hyvän elämän edellytyksiä jo paljon ennen vanhuusikää.

Beyond Successful and Active Ageing on napakka noin sadan sivun puheenvuoro monimuotoisemman vanhuuden kuvaston puolesta. Tutkimuksellisesti ja teoreettisesti kirjan anti ei ole niinkään uuden luomisessa, mutta hallitsevia onnistuneen vanhuuden diskursseja analysoidaan tarkkanäköisesti. Timonen laittaa lukijansa miettimään, mitä itse voisi tutkijana tai yhteiskunnallisena osallistujana omassa ammatissaan tehdä, jotta yhteiskunnan monimuotoisuus ja erilaiset sosiaaliset, taloudelliset ja kulttuuriset todellisuudet ulottuisivat myös vanhuuden tutkimukseen. 